\title{
Phenology of pelagic seabird abundance relative to marine climate change in the Alaska Gyre
}

\author{
Sarah Ann Thompson ${ }^{1, *}$, William J. Sydeman ${ }^{1}$, Jarrod A. Santora ${ }^{1}$, Ken H. Morgan², \\ William Crawford ${ }^{3}$, Michael T. Burrows ${ }^{4}$ \\ ${ }^{1}$ Farallon Institute for Advanced Ecosystem Research, Petaluma, California 94952, USA \\ ${ }^{2}$ Canadian Wildlife Service, Environment Canada, c/o Institute of Ocean Sciences, Sidney, British Columbia V8L4B2, Canada \\ ${ }^{3}$ Fisheries and Oceans Canada, Institute of Ocean Sciences, Sidney, British Columbia V8L4B2, Canada \\ ${ }^{4}$ Department of Ecology, Scottish Association for Marine Science, Oban, Argyll PA371QA, UK
}

\begin{abstract}
In relation to climate change, a common finding from long-term studies on marine ecosystems is earlier annual peaks of abundance for many organisms. Here, we test the hypothesis of unidirectional change in the seasonal abundance of pelagic seabirds in association with change in marine climate and primary productivity in the Alaska Gyre. To test this hypothesis, we analyzed data on hydrographic conditions and seasonal at-sea abundance of seabirds along a $1425 \mathrm{~km}$ transect (Line P) over 11 yr, 1996 to 2006. Long-term sea surface temperature (SST) data show warming in the study region, advanced and delayed temperature peaks and northwestward isotherm displacement. Using negative binomial regression, we tested seasonal trends in the relative abundance of 15 seabird species and compared abundances to a multivariate ocean climate index we developed with principal component analysis from in situ measurements of water temperature, salinity, density and nitrate concentrations. Overall, 5 species showed no change, 1 declined, and 9 species as well as all species combined showed increasing abundance. By season, 3 species increased in winter, 7 in late spring, and 6 in late summer. Eight of 15 species showed relationships with our environmental index. Increases in seasonal seabird abundance may be related to lengthening of the 'growing season', as demonstrated by temporal temperature shifts and expansion of peak chlorophyll concentrations. Seabirds of the Alaska Gyre are probably responding to changes in forage nekton that are related to this extended growing season by shifting their migration to later dates.
\end{abstract}

KEY WORDS: Birds $\cdot$ Climate $\cdot$ Chlorophyll $\cdot$ Growing season $\cdot$ Migration timing $\cdot$ Sub-arctic ecosystem

\section{INTRODUCTION}

Climate change affects marine ecosystems worldwide, with impacts on distribution and abundance, phenology, and productivity of species, and, in turn, species interactions, community organization, and ecosystem functions and services (reviewed by Hoegh-Guldberg \& Bruno 2010, Doney et al. 2012). To date, one of the most robust findings from longterm marine observations is earlier seasonality of abundance in plankton populations (Edwards \&
Richardson 2004, Beaugrand \& Kirby 2010, Ji et al. 2010). Such effects have been particularly well-documented in the North Atlantic. Fewer studies have been conducted in the North Pacific, but similar findings have been obtained, showing, for example, earlier seasonal peaks in abundance of large, energy-rich Neocalanus copepods in the Gulf of Alaska (Mackas et al. 1998, Bertram et al. 2001, Batten \& Mackas 2009). The phenology of plankton abundance is critical to trophic interactions; if plankton are not available at the right time and place, the 
foraging ecology of predatory nekton may be compromised, possibly leading to reduced recruitment and population declines in upper trophic-level species (Cushing 1990, Mackas et al. 2007, Sydeman et al. 2009, Dorman et al. 2011).

Seabirds are the most conspicuous marine organisms living at the interface of the ocean and atmosphere and have been put forth as reliable indicators of variability of the abundance of plankton and forage nekton populations (Piatt et al. 2007). As an ecotone, the surface and near-surface habitats of seabirds may be affected by climate change as global warming heats the atmosphere thereby affecting these upper ocean habitats (Levitus et al. 2005). While there have been many studies of climate change impacts on seabird phenology at colonies, examining parameters such as date of colony arrival (Barbraud \& Weimerskirch 2006) and hatching dates of eggs (Byrd et al. 2008), long-term observational studies of seabird communities at sea are few, and almost none are conducted across multiple seasons (but see Hyrenbach \& Veit 2003, Sydeman et al. 2010). Most studies of seabird populations at sea have, however, demonstrated responses to marine climate variability and change over multiple time scales (Hyrenbach \& Veit 2003, Sydeman et al. 2009, Ainley \& Hyrenbach 2010), so assuming that seasonal changes in abundance should also be observed is logical. To date, though, no study has attempted to corroborate the key findings on plankton described above using upper trophic-level species. We define variation in the phenology of seabirds at sea as a change in seasonal abundance through time. This may reflect changes in migration timing, especially for southern hemisphere species, or changes in wintering ecology for resident breeders.

In the North Pacific, the Gulf of Alaska (GoA) marine ecosystem is comprised of coastal and offshore waters from southern British Columbia north to Cook Inlet, Alaska, and west to the outer Aleutian Islands. The GoA is a highly productive marine ecosystem with substantial fisheries resources. In the southeastern sector, the Canadian 'Line $\mathrm{P}^{\prime}$ survey (Fig. 1; www.pac.dfo-mpo.gc.ca/science/oceans/datadonnees/line-p/index-eng.htm) is one of only 2 longterm (>50 yr) interdisciplinary studies in the Northeast Pacific; the other is the California Cooperative Oceanic Fisheries Investigations (CalCOFI) off southern California (Hsieh et al. 2009). The Line P program has provided a wealth of information about change in ocean climate in the southeastern GoA. Key findings include: (1) increasing temperature and decreasing salinity (i.e. freshening of the surface layer, Freeland

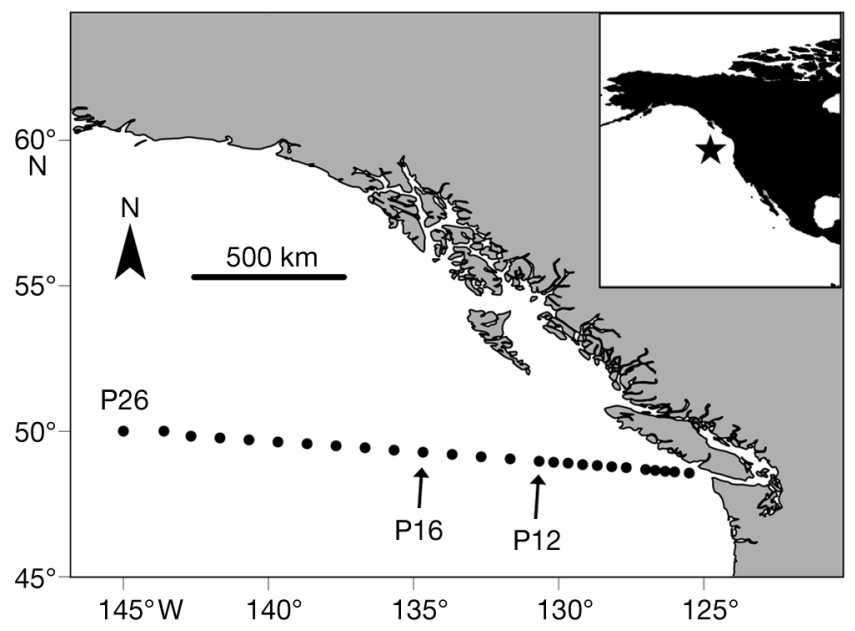

Fig. 1. Northeast Pacific. Position of the Line P survey transect and the locations of survey stations. Physical data were collected at Stns P12 $\left(48.97^{\circ} \mathrm{N}, 130.67^{\circ} \mathrm{W}\right), \mathrm{P} 16\left(49.28^{\circ} \mathrm{N}\right.$, $134.67^{\circ} \mathrm{W}$ ) and P26 (Station Papa; $50.00^{\circ} \mathrm{N}, 145.00^{\circ} \mathrm{W}$ )

et al. 1997); (2) increasing density stratification due to surface layer warming and freshening (Crawford et al. 2007); (3) shoaling of winter pycnocline depth (Freeland \& Cummins 2005); and (4) reduced annual re-supply of macronutrients (Whitney \& Freeland 1999, see Sarkar et al. 2005 for similar information about the northern GoA). Changes in phenology of the zooplankton described above are likely related to these changes in the physical environment along Line P. Moreover, interannual variation in the abundance of many commonly occurring seabirds is substantial (Yen et al. 2005). Seabird distribution and abundance in this region has been related to gradients in sea surface temperature (SST) associated with frontal structures (O'Hara et al. 2006). While Yen et al. (2005) and O'Hara et al. (2006) provide initial information on this seabird community, a thorough investigation of seabird populations relative to ocean climate along Line $\mathrm{P}$ has yet to be conducted.

We present an analysis of seasonal variation in the abundance of seabirds in the Alaska Gyre to test the hypothesis of unidirectional change in the seasonality of pelagic seabird abundance in association with trends in marine climate and primary productivity as measured through chlorophyll a (chl a) concentration. Changes in SST are presented on a broad temporal and spatial scale using Hadley Center data. To test our hypothesis, we analyzed data on the at-sea abundance of seabirds and concurrent hydrographic conditions along the Line $\mathrm{P}$ transect in 3 seasons over 11 yr (1996 through 2006). Specifically, we examine if there were trends in the abundance of 15 seabird species relative to an environmental index and sea- 
sonality. This study is important as the potential effect of climate variability and change on seabird communities in the GoA has yet to be investigated, and this ecosystem may provide interesting contrasts to the adjacent California Current where we have concurrent data on the seasonal abundance of seabirds from the CalCOFI region (Hyrenbach \& Veit 2003, Sydeman et al. 2009).

\section{MATERIALS AND METHODS}

\section{Variability and change in ocean climate}

We used SST data from 1960 through 2009 to assess broad-scale temperature change $\left({ }^{\circ} \mathrm{C} \mathrm{yr}^{-1}\right)$, the 'velocity' of climate change (isotherm displacement in $\mathrm{km} \mathrm{yr}^{-1}$ ) and seasonal shifts in temperature (d decade $^{-1}$ ) for April and October focused on the Alaska Gyre. Data were obtained from the Hadley Center (HadISST; badc.nerc.ac.uk/view/badc.nerc. ac.uk_ATOM_dataent_hadisst) and processed as described by Burrows et al. (2011). We extracted temperature data from the $1^{\circ} \times 1^{\circ}$ pixels that encompass the locations of the Line $\mathrm{P}$ survey stations listed below.

Locally, measurements of temperature $\left({ }^{\circ} \mathrm{C}\right)$, practical salinity, and nitrate concentrations $\left(\mu \mathrm{mol} \mathrm{l}^{-1}\right)$ were measured in situ by Niskin bottles and CTD (Seabird SBE 911+) casts at stations along the Line P transect from 1996 through 2006. To simplify the analysis, we used data from 3 main offshore stations: P12 $\left(48.97^{\circ} \mathrm{N}, 130.67^{\circ} \mathrm{W}\right), \mathrm{P} 16\left(49.28^{\circ} \mathrm{N}, 134.67^{\circ} \mathrm{W}\right)$, and P26 (Ocean Station Papa; $50.00^{\circ} \mathrm{N}, 145.00^{\circ} \mathrm{W}$; Fig. 1). Data from these stations were used previously in studies of temporal environmental variability of the Alaska Gyre (Lipsen et al. 2007, Peña \& Varela 2007, Wong et al. 2007). Water column density (sigma-t) was calculated from temperature, salinity and pressure. Data were summarized for $10 \mathrm{~m}$ depth intervals and averaged to produce seasonal values. In addition, seasonal averages were calculated and used to proxy missing values (seasons) in the data set. Finally, the 1996-2006 seasonal averages were subtracted from seasonal values to produce anomaly statistics that were used in analyses.

\section{Ocean surface chlorophyll}

Satellite remotely-sensed chlorophyll concentration $\left(\mathrm{mg} \mathrm{m}^{-3}\right)$ data were obtained from the Sea-viewing Wide Field-of-View Sensor (SeaWiFS) for 1998 to
2006. For consistency with measurements of hydrographic conditions, we used monthly composites of $9 \times 9 \mathrm{~km}$ cells situated at the coordinates of Stns P12, P16 and P26. We averaged the chlorophyll values for the cell closest to the coordinates of the station and cells immediately to the east, south, and southeast to produce an overall estimate for $324 \mathrm{~km}^{2}$ of ocean habitat at each station. The average concentration from the 4 cells at each station was averaged across the 3 stations to produce a single value for each seasonal Line P survey.

\section{Seabird surveys}

From June 1996 to June 2006, we conducted 28 seabird surveys along the Line $\mathrm{P}$ transect. Most surveys were conducted over 10 to $20 \mathrm{~d}$ aboard the Canadian Coast Guard Ship 'John P. Tully'. The timing of winter (February), late spring (June), and late summer (August to September) seasonal surveys was variable, but did not change systematically over the $11 \mathrm{yr}$ ( $\mathrm{p}>0.1$ for each season). The median date of each survey is listed in Appendix Table 1. There was variability in the length of surveys, but the duration of surveys did not change significantly through time $(p>0.05)$. Related in part to survey duration, there was substantial variation in the area of ocean habitat surveyed for seabirds, but again we found no trend in coverage over the study period ( $p>0.2)$.

Data on seabird populations were collected as described by Yen et al. (2005) and O'Hara et al. (2006). Briefly, birds were counted by an experienced observer positioned on the flying bridge, $\sim 15 \mathrm{~m}$ above the water surface. Surveys were conducted using the standard strip transect method (Tasker et al. 1984). All birds sighted within $250 \mathrm{~m}$ of the ship in a $90^{\circ}$ arc from the bow to amidship on the side of the ship with least glare were identified and enumerated. Surveys were conducted during daylight hours while the ship was underway at $>5$ knot; observations were halted during periods of inclement weather or when visibility or ability to spot and identify birds out to $250 \mathrm{~m}$ was compromised.

We summarized seabird observations into daily counts and converted them into density estimates (birds $\mathrm{km}^{-2}$ ) by dividing counts by the area surveyed each day. We included species with at least 200 individuals observed over the duration of our study to exclude species with insufficient data for trend analyses. We did not conduct a power analysis on these data because the variance structure was unknown a priori. This procedure resulted in selection of 15 species 
(Appendix Table A2), as well as a total for all species. Due to difficulties in distinguishing sooty shearwaters (Puffinus griseus) and short-tailed shearwaters $(P$. tenuirostris), these species were identified as 'dark' shearwaters for analysis. In terms of the use of 'day' as our fundamental sampling unit, in comparison to the finer spatio-temporal resolutions that others have used, we used daily counts to avoid problems of pseudo-replication, excessive sample size, and spatial autocorrelation (see Yen et al. 2005 for an analysis of spatial autocorrelation for this seabird data set). These issues affect estimates of probabilities on temporal trends as well as environmental (climate) correlates, as the degrees of freedom are unknown due to varying spatial autocorrelation functions between species. We avoided these problems by using 'day' as our sampling unit, which separated surveys by nighttime hours when no seabird observations were made. Moreover, we excluded data collected during the first day of each survey to exclude observations from the coastal domain. In general, the vessel transits of coastal regions (shallow waters to $\sim 1000 \mathrm{~m}$ depth) took $<4 \mathrm{~h}$. Daily density estimates (no. of birds $\mathrm{km}^{-2}$ $\mathrm{d}^{-1}+1$ ) were $\log _{10}$ transformed for illustration.

\section{Data analysis}

Data were analyzed using Stata v. 11 (Stata). To test for trends in hydrography, we used Spearman rank correlations and linear regression. We used principal component analysis (PCA) to create a local multivariate marine climate index time series. The PCA was conducted on the 4 in situ hydrographic variables of temperature, salinity, sigma-t, and nitrate concentration. This analysis was restricted to data collected concurrently with seabird observations made during surveys from June 1996 to June 2006. The first principal component was retained for further analysis (environment PC1, hereafter 'PC1 $1_{\text {env }}$ '). We used rank correlations to test for trends in seasonal peak chlorophyll concentrations, changes in the timing of seasonal peaks, and a relationship between chlorophyll concentration and $\mathrm{PC} 1_{\text {env }}$. To look for trends in the timing of seasonal peaks, correlations were conducted on the month number of the peak across years. We calculated the number of months between the occurrences of the peaks and tested the difference over the time series to look for a trend in the temporal spacing of the peaks and length of the growing season.

We used negative binomial regression to test for trends in the seasonal abundance of seabirds. Nega- tive binomial regression is designed for analysis of count data (Hilbe 2011), such as the seabird data described herein. Daily counts were used to test for trends, and 'area surveyed' was included as a covariate to adjust for survey effort. To investigate seabirdenvironment relationships, $\mathrm{PC} 1_{\text {env }}$ was aligned with the seasonal seabird count data and also lagged by 1 survey (i.e. a lag of $4 \mathrm{mo}$ ).

\section{RESULTS}

\section{Trends in environment and seabirds}

The HadISST data illustrate long-term and spatial patterns of change in the Northeast Pacific and Alaska Gyre (Fig. 2). Over 50 yr (1960 to 2009), there was an increase in temperature, a shift in isotherms toward the center of the Alaska Gyre, and earlier and later shifts in temperature. For each survey station, temperature increased significantly through time (P12: Spearman $\rho=0.40, \mathrm{p}=0.0045$; P16: Spearman $\rho=0.48, p=0.0004$; P26: Spearman $\rho=0.39, p=$ 0.0053 ). The (mean $\pm \mathrm{SE}$ ) rate of temperature change for each station varied from $0.014 \pm 0.005$ (P26) to

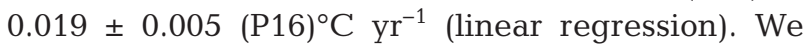
found no significance of quadratic fits to these data. For the central Gulf of Alaska and Line $\mathrm{P}$ region, isotherm displacement ranged from 5 to $10 \mathrm{~km} \mathrm{yr}^{-1}$ (Fig. 2). Finally, these data indicate a seasonal shift in temperature, with an advance of $\sim 8 \mathrm{~d}$ decade $^{-1}$ in April and a delay of $\sim 3 \mathrm{~d}_{\text {decade }}^{-1}$ in October (Fig. 2).

$\mathrm{PC}{ }_{\text {env }}$ captured $62 \%$ of the variance, with temperature and sigma-t loading most heavily (Table 1). Through time, $\mathrm{PC} 1_{\text {env }}$ was somewhat variable prior to 1999 and more stabilized thereafter (Fig. 3). The second principal component accounted for $25 \%$ of the variance and loaded very highly on nitrates (Table 1). We used the first principal component for our study as a representation of environmental conditions.

Monthly chlorophyll concentration over time is presented in Fig. 4. The seasonal cycle of early and late blooms is evident, with the highest values occurring in October 2005 and 2006. We found no change in the amplitude of peak values for each season. We found significant change in the timing of the peaks, with the early peak becoming earlier (Spearman $\rho=$ $-0.718, p=0.029$ ) and the late peak becoming later (Spearman $\rho=0.572, p=0.108$; see Table 2 for data). With the late spring peak becoming earlier and the late summer peak becoming later, the number of months between peaks increased (Spearman $\rho=$ $0.845, p=0.004)$. We found no significant correlations 



Velocity

SST Annual mean

$\left(\mathrm{km} \mathrm{yr}^{-1}\right)$

$>20$

10 to 20

5 to 10

2 to 5

1 to 2

0.5 to 1

-0.5 to 0.5

-1 to -0.5

-2 to -1

-5 to -2

-10 to -5

-20 to -10

$145^{\circ} \mathrm{W} \quad 140^{\circ} \quad 135^{\circ} \quad 130^{\circ} \quad 125^{\circ}$
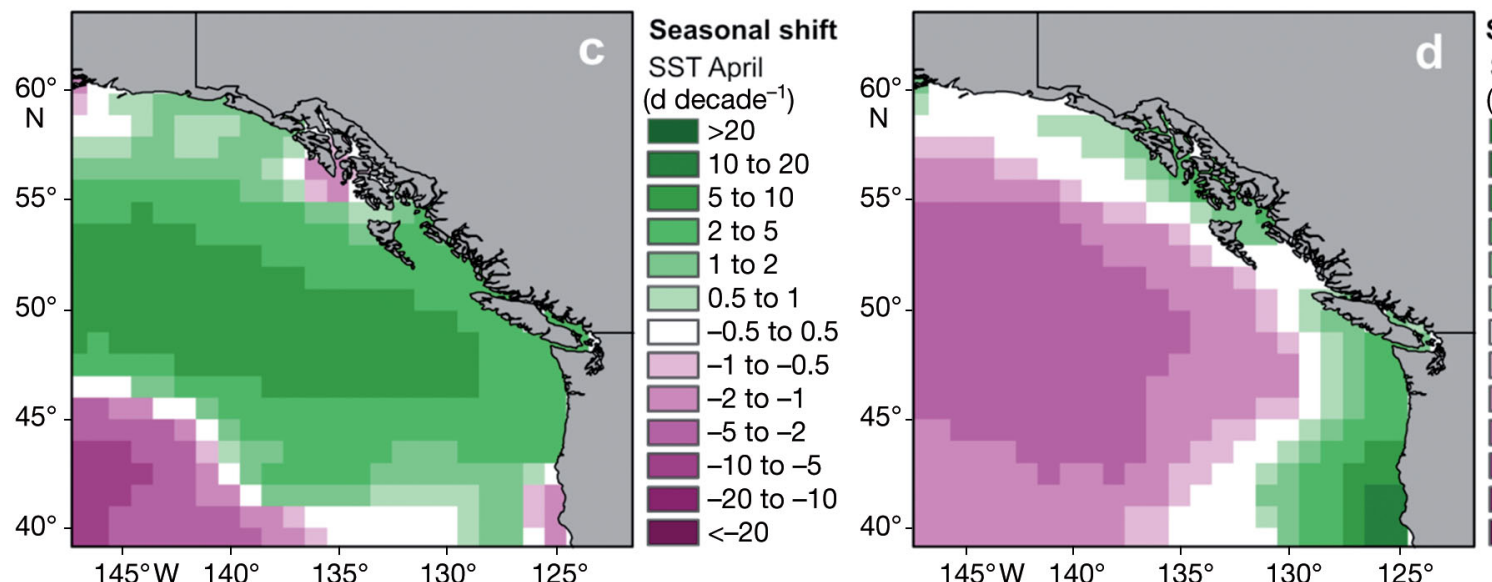

Seasonal shift

SST October

(d decade de $^{-1}$

10 to 20

5 to 10

2 to 5

1 to 2

0.5 to 1

-0.5 to 0.5

-1 to -0.5

-2 to -1

-5 to -2

-10 to -5

-20 to -10

$<-20$

Fig. 2. Sea surface temperature trends (HadISST) in the Northeast Pacific. (a) Temperature trend for 1960 to 2009 ; the maximum change offshore $=0.25^{\circ} \mathrm{C}_{\text {decade }}{ }^{-1}$. Note cooling along the coast of Oregon and northern California. (b) Directionality in the velocity of change in the mean annual sea-surface temperature (SST) isotherms; maximum change $=11.3 \mathrm{~km}_{\mathrm{yr}}^{-1}$. The direction along Line $\mathrm{P}$ is northwestern, and the vectors shown generally are directed toward the center of the Alaska Gyre. Negative values indicate a decrease in temperature. Bottom panels: Phenological shifts of April and October SST. (c) Maximum advance (earlier occurrence) of April SST by $\sim 8 \mathrm{~d}_{\text {decade }}{ }^{-1}$ shown, all corresponding to the Line P region in the Alaska Gyre. (d) Maximum delay of October SST by $\sim 3$ d decade ${ }^{-1}$, particularly in the outer region of Line P. See Burrows et al. (2011) for methods of SST, velocity, and phenology shift calculations

between chlorophyll concentration and $\mathrm{PC} 1_{\text {env }}$.

We found seasonal variability and directional change in seabird species abundance (Table 3, Figs. 5, 6 \& 7). Four species showed episodic high densities, illustrated by 1 or 2 disproportionately large bars in the density values (e.g. mottled petrel Pterodroma inexpectata peak in late spring 2002, Fig. 6; ancient murrelet Synthliboramphus antiquus peak in late spring 1997, Fig. 5; pink-footed shearwater Puffinus creatopus peak in late summer 2001, Fig. 6). Two species were completely absent from surveys in a season: pink-footed shearwaters (winter, Fig. 6) and ancient murrelet (late sum-
Table 1. Environmental principal component analysis (PCA). Variables included were seasonal anomalies of temperature, salinity, nitrates and sigma-t

\begin{tabular}{|lcccc|}
\hline $\begin{array}{l}\text { Principal } \\
\text { component }\end{array}$ & Eigenvalue & Difference & $\begin{array}{c}\text { Proportion } \\
\text { of variance }\end{array}$ & $\begin{array}{c}\text { Cumulative } \\
\text { variance }\end{array}$ \\
\hline 1 & 2.499 & 1.463 & 0.625 & 0.625 \\
2 & 1.036 & 0.579 & 0.259 & 0.884 \\
3 & 0.458 & 0.450 & 0.114 & 0.998 \\
4 & 0.008 & & 0.002 & 1.000 \\
Eigenvector & & & & \\
Variable & 1 & 2 & 3 & 4 \\
\hline Temperature & -0.583 & -0.152 & 0.523 & 0.603 \\
Salinity & 0.457 & -0.509 & 0.676 & -0.273 \\
Nitrates & 0.258 & 0.839 & 0.477 & 0.048 \\
Sigma-t & 0.621 & -0.117 & -0.205 & 0.748 \\
\hline
\end{tabular}




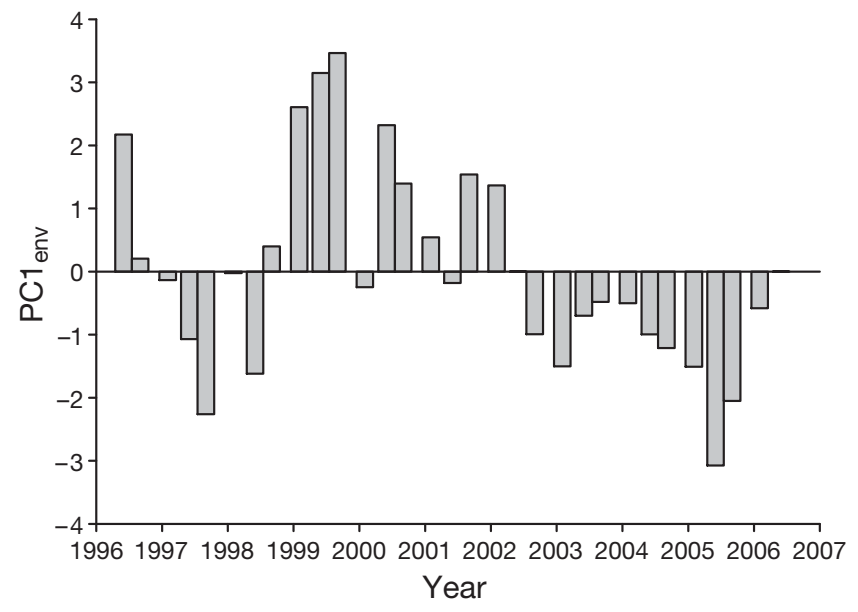

Fig. 3. Time series of principal component $1\left(\mathrm{PC} 1_{\text {env }}\right), 1996$ to 2006. Positive values of PC1 indicate cold periods, whereas negative values indicate warm periods

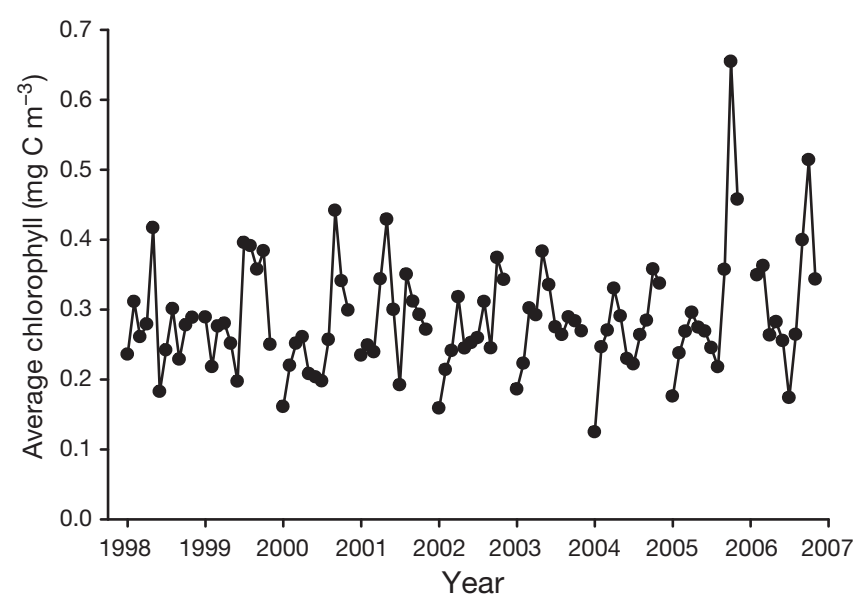

Fig. 4. Monthly chlorophyll concentrations on Line P, 1998 to 2006, derived from the Sea-viewing Wide Field-of-view Sensor (SeaWiFS). Year ticks indicate January of each year

Table 2. Months of early and late peaks in chlorophyll concentration along Line $\mathrm{P}, 1998$ to 2006 and the amount of time between the peak concentrations

\begin{tabular}{|c|c|c|c|}
\hline \multirow[t]{2}{*}{ Year } & \multicolumn{2}{|c|}{$\longrightarrow$ Month of $\longrightarrow$} & \multirow{2}{*}{$\begin{array}{c}\text { Time between } \\
\text { peaks (no. of mo) }\end{array}$} \\
\hline & early peak & late peak & \\
\hline 1998 & May & August & 3 \\
\hline 1999 & July & October & 3 \\
\hline 2000 & April & September & 5 \\
\hline 2001 & May & August & 3 \\
\hline 2002 & April & October & 6 \\
\hline 2003 & May & September & 4 \\
\hline 2004 & April & October & 6 \\
\hline 2005 & April & October & 6 \\
\hline 2006 & March & October & 7 \\
\hline
\end{tabular}

mer, Fig. 5). Four species were excluded from the negative binomial regression analysis in 1 season because of very low counts: black-legged kittiwake Rissa tridactyla in late spring, dark shearwaters and Leach's storm-petrel Oceanodroma leucorhoa in winter, and Laysan albatross Phoebastria immutabilis in late summer. After omitting these species from analysis, we found winter had the fewest trends in seabird abundance while late summer had the most (Table 3). Laysan albatross (winter, Fig. 7) was the only species to show a significant decrease in abundance (Table 3). Two-thirds of the species showed increasing abundance. Total (all species) abundance increased overall as well as in every season, as did rhinoceros auklet Cerorhinca monocerata abundance (Table 3, Fig. 5).

\section{Relationships between seabird abundance and the environment}

The seasonal abundances of 4 species (rhinoceros auklet, glaucous-winged gull Larus glaucescens, dark shearwaters and Leach's storm-petrel) and all species combined correlated with $\mathrm{PC}_{\mathrm{env}}$ at lags of both 0 and 4 mo (Table 4). Four species were negatively correlated with $\mathrm{PC} 1_{\text {env }}$ at either lag 0 or lag 4 mo: ancient murrelet and Cassin's auklet Ptychoramphus aleuticus at lag 0 (concurrent environmental and seabird measurements) and black-footed albatross Phoebastria nigripes and fork-tailed stormpetrel Oceanodroma furcata at lag 4 mo (environment leading seabirds; Table 4). Seven species (common murre Uria aalge, tufted puffin Fratercula cirrhata, black-legged kittiwake, mottled petrel, northern fulmar Fulmarus glacialis, pink-footed shearwater and Laysan albatross) had no significant relationships (Table 4). We found a significant correlation between the length of the growing season (as indexed by the number of months between early and late chlorophyll peaks) and total bird abundance in the late spring (Spearman rho $=0.725, \mathrm{p}=0.027$ ), but no significant relationships for winter or late summer abundances (respectively, Spearman rho $=0.207, \mathrm{p}=$ 0.593 and rho $=0.075, p=0.873$ ).

\section{DISCUSSION}

We investigated the hypothesis of change in the seasonal abundance of pelagic seabirds relative to change in marine climate and productivity (indexed by chl a concentrations) in the Alaska Gyre. Using 
the HadISST data, we demonstrated warming, poleward shifts in isotherms and seasonal shifts in average temperature, indicating long-term environmental change that may be attributable to anthropogenic global warming. Despite a relatively short timeseries of seabird observations (11 yr) punctuated with the characteristic episodic variability in seabird densities observed in many studies (e.g. Ainley \& Hyrenbach 2010), our primary result is an increase in the relative abundance of seabirds in the study region (10 of 15 species), with the most compelling change occurring during late summer (August to September). Increasing abundance of all species combined was found in all seasons. In winter (February) Laysan albatross abundance decreased, while 3 species (rhinoceros auklet, tufted puffin, and glaucous-winged gull) increased. In late spring (June), 4 species (Cassin's auklet, dark shearwaters, fork-tailed stormpetrels and Leach's storm-petrels) increased; in late summer, 6 species (common murre, rhinoceros auklet, dark shearwaters, black-footed albatross and both species of storm-petrels) increased. Four species (ancient murrelet, black-legged kittiwake, mottled petrel and northern fulmar) did not show any change in abundance. Overall, there appears to have been a general increase in seabird abundance in the study region over the $11 \mathrm{yr}$, with the greatest shift towards increasing abundance later in late summer.

\section{Internal and external drivers of change}

The population changes demonstrated here could reflect internal (species- or population-specific) or external (environmental) factors. Recent studies indicate the following population trends for locallybreeding seabirds in British Columbia: tufted puffin breeding populations are stable, rhinoceros auklet populations are increasing, and Cassin's auklet and common murre populations are declining (19842009; Rodway \& Lemon 2011). Hipfner (2005) attributes the change in murre populations (2003-2004) to differences in colony attendance driven by the presence or absence of predatory bald eagles Haliaeetus leucocephalus. Information on locally-breeding forktailed storm-petrel population is inadequate to assess trends (M. Hipfner pers. comm.). Population trends from breeding sites for the migrant species are also indicative, primarily, of declining trends. Sooty shearwaters have declined $37 \%$ over 27 yr (1969-1996) at breeding colonies in New Zealand (Scott et al. 2008), and pink-footed shearwaters have declined from colonies in Chile (Schlatter 1984).
Since many seabird species show population declines at colonies, yet we found increased abundance at sea in the Alaska Gyre, we suggest external factors may explain our observations, with environmental correlations supporting this supposition. There are, however, a number of caveats to this suggestion. (1) Most of the studies referenced above focused on breeding birds and did not consider the non-breeding component of these populations, which largely remain at sea throughout the year. For these species it is possible, though unlikely, that nonbreeding birds increased while the breeding component did not, therefore resulting in an increase in relative abundance at sea. (2) A related point is that with deferred reproduction, breeding populations could decline while abundance at sea, if represented by non-breeders, could increase. However, there are also temporal limits to consider. Deferred reproduction and non-breeding for most of these seabird species lasts up to 6 to $8 \mathrm{yr}$, while the patterns of population change we observed extended over an 11 yr period.

\section{Seabird-environmental correlates on multiple time scales}

The environmental variables we measured during surveys were highly correlated with each other (results not shown) and thus could suitably be combined using PCA. This is expected since temperature and salinity are inversely related and sigma-t is a factor of temperature, salinity and pressure. Importantly, these data came from measurements well offshore and away from freshwater sources that would affect salinity. The resulting multivariate indicator, $\mathrm{PC}_{\text {env' }}$ reflects interannual variation in water column conditions. Temperature loaded negatively while salinity and sigma-t loaded positively on PC1 $1_{\text {env }}$ Temperature and sigma-t probably contributed most to the correlations between seabird abundance and this principal component.

Regarding interannual variability, we found few correlations between seabird abundances and individual hydrographic measurements (S. A. Thompson $\&$ W. J. Sydeman unpubl. data). However, we found significant correlations between $\mathrm{PC} 1_{\text {env }}$ and seabird abundances; 8 of 15 species and all species combined showed significant relationships. In general, we found decreasing abundance of seabirds with increasing $\mathrm{PC} 1_{\text {env }}$. These inverse relationships reflect the 'PC1 space' that was created by combining the physical parameters using PCA. To reiterate, temperature was 
Table 3. Negative binomial regression on seabird abundance over time by season (winter: 1997-2006; late spring: 1996-2004, 2006; and late summer: 1996, 1999-2005). The model for all seasons included terms for area, year (continuous), and season (categorical). The model for each season included terms area and year (continuous). The sign of any significant trend is noted next to species names (NC: no change). Dark shearwaters consist of both sooty and short-tailed species. nd: not detected; ${ }^{*} \mathrm{p}<0.1,{ }^{* *} \mathrm{p}<0.05,{ }^{* * *} \mathrm{p}<0.01$

\begin{tabular}{|c|c|c|c|c|c|c|c|c|}
\hline \multirow[b]{2}{*}{ Species } & \multicolumn{2}{|c|}{ — All seasons —— } & \multicolumn{2}{|c|}{ Winter -} & \multicolumn{2}{|c|}{ — Late spring _- } & \multicolumn{2}{|c|}{ _ Late summer } \\
\hline & Coefficient & $Z$-score & Coefficient & Z-score & Coefficient & $Z$-score & Coefficient & Z-score \\
\hline All species (+) & 0.151 & $7.21^{* * *}$ & 0.093 & $3.03^{* * *}$ & 0.167 & $4.7^{* * *}$ & 0.235 & $5.78^{* * *}$ \\
\hline \multicolumn{9}{|l|}{ Alcids } \\
\hline Ancient murrelet (NC) & -0.016 & -0.12 & 0.179 & 0.99 & -0.189 & -1.02 & nd & nd \\
\hline Cassin's auklet (+) & 0.164 & $1.90^{*}$ & 0.133 & 0.84 & 0.344 & $2.79^{* * *}$ & -0.036 & -0.20 \\
\hline Common murre $(+)$ & 0.272 & $2.59^{* * *}$ & 0.196 & 1.34 & 0.178 & 1.27 & 0.904 & $3.21^{* * *}$ \\
\hline Rhinoceros auklet (+) & 0.308 & $4.31^{* * *}$ & 0.394 & $3.56^{* * *}$ & 0.208 & $1.65^{*}$ & 0.373 & $2.78^{* * *}$ \\
\hline Tufted puffin (+) & 0.057 & 1.21 & 0.175 & $2.88^{* * *}$ & -0.018 & -0.25 & 0.041 & 0.23 \\
\hline \multicolumn{9}{|l|}{ Larids } \\
\hline Black-legged kittiwake (NC) & 0.052 & 0.75 & 0.059 & 1.13 & nd & nd & -0.284 & -0.46 \\
\hline Glaucous-winged gull (+) & 0.207 & $3.34^{* * *}$ & 0.191 & $3.51^{* * *}$ & 0.158 & 0.94 & 0.368 & 1.39 \\
\hline \multicolumn{9}{|l|}{ Procellarids } \\
\hline Mottled petrel (NC) & 0.044 & 0.57 & -0.023 & -0.29 & 0.101 & 0.54 & 0.112 & 0.52 \\
\hline Northern fulmar (NC) & 0.072 & 1.58 & 0.042 & 1.08 & 0.148 & 1.30 & 0.003 & 0.02 \\
\hline Pink-footed shearwater (+) & 0.761 & $2.14^{* *}$ & nd & nd & 0.770 & $1.74^{*}$ & 0.463 & 0.64 \\
\hline Dark shearwaters (+) & 0.283 & $4.76^{* * *}$ & nd & nd & 0.172 & $2.63^{* * *}$ & 0.454 & $4.34^{* * *}$ \\
\hline \multicolumn{9}{|l|}{ Albatrosses } \\
\hline Black-footed albatross (+) & 0.077 & $2.14^{* *}$ & -0.103 & -1.37 & 0.104 & $1.70^{*}$ & 0.189 & $3.91^{* * *}$ \\
\hline Laysan albatross (-) & -0.169 & $-3.32^{* * *}$ & -0.159 & $-2.90^{* * *}$ & -0.216 & -1.45 & nd & nd \\
\hline \multicolumn{9}{|l|}{ Storm-petrels } \\
\hline Fork-tailed storm-Petrel (+) & 0.100 & $3.38^{* * *}$ & 0.009 & 0.19 & 0.095 & $2.14^{* *}$ & 0.237 & $3.88^{* * *}$ \\
\hline Leach's storm-Petrel (+) & 0.150 & $4.77^{* * *}$ & nd & nd & 0.141 & $3.64^{* * *}$ & 0.167 & $3.12^{* * *}$ \\
\hline
\end{tabular}
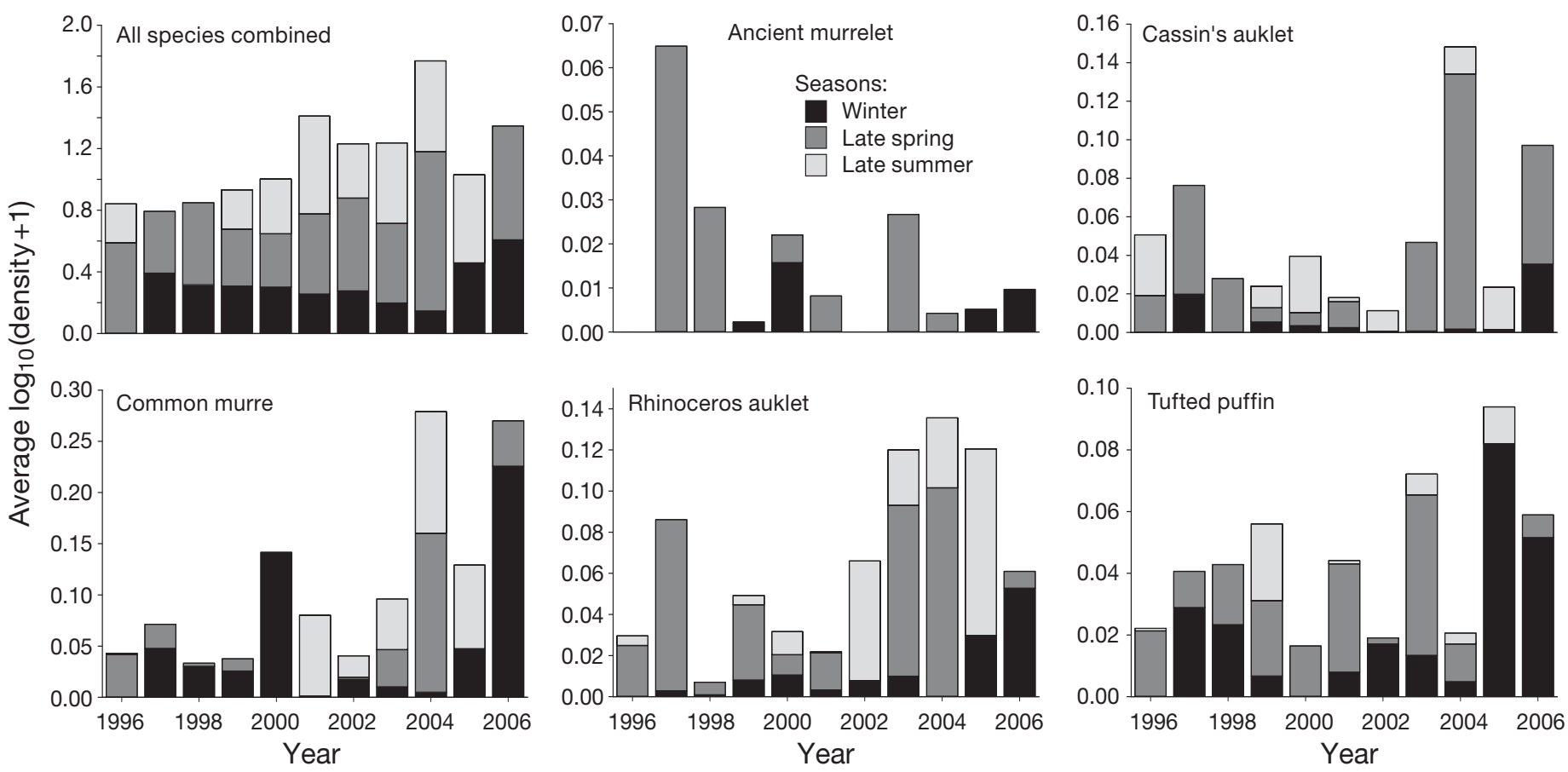

Fig. 5. Synthliboramphus antiquus, Ptychoramphus aleuticus, Uria aalge, Cerorhinca monocerata, and Fratercula cirrhata. Seasonal average $\log _{10}($ density +1$)$ of all species combined and alcids individually. Seasons see key 

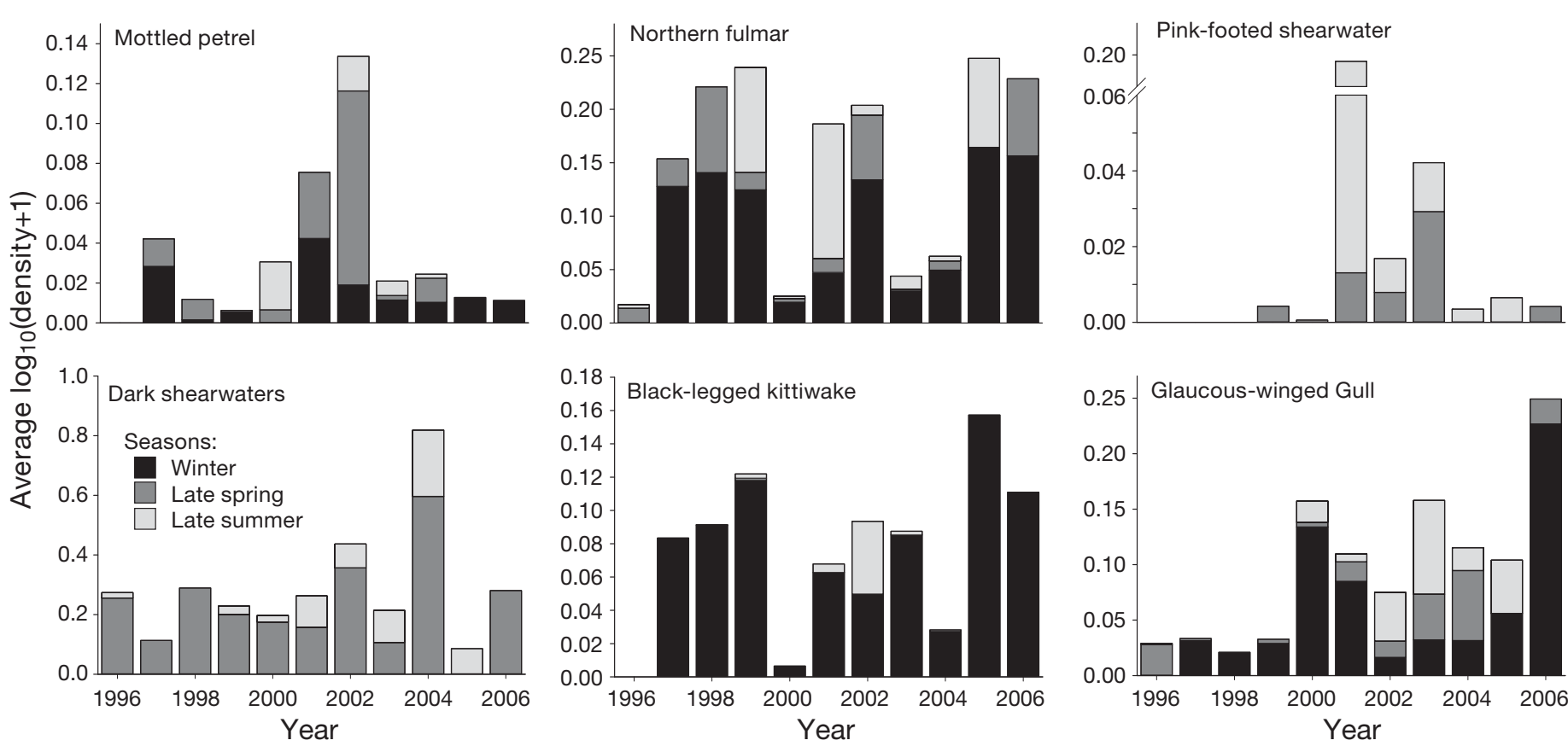

Fig. 6. Seasonal average $\log 10($ density +1 ) of procellarids and larids. Seasons see key. Dark shearwaters consist of both sooty and short-tailed species. See Appendix Table A2 for scientific names

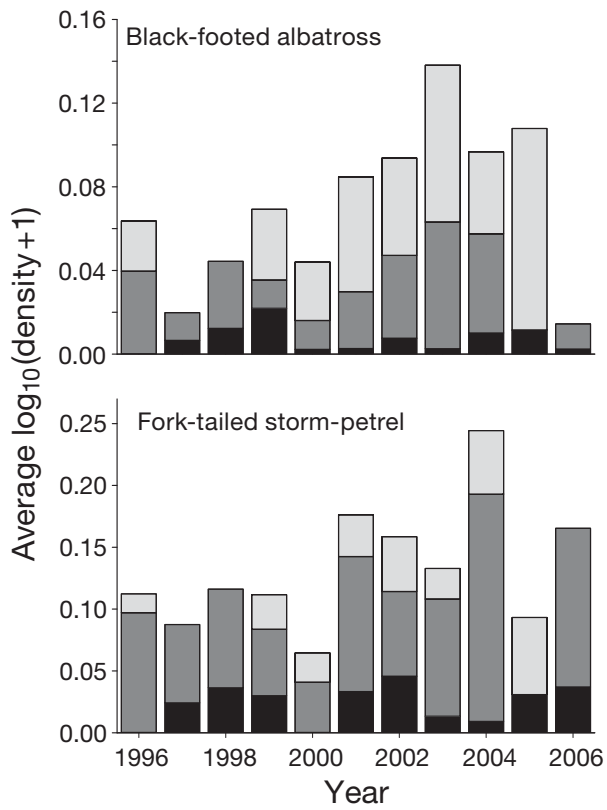

Fig. 7. Phoebastria nigripes, P. immutabilis, Oceanodroma furcata and O. leucorhoa. Seasonal average $\log _{10}($ density +1$)$ of albatrosses and storm-petrels. Seasons see key

negatively related to $\mathrm{PC} 1_{\mathrm{env}}$ and salinity and sigma-t were positively related. This means that the relationships between seabird abundance and temperature were actually positive (negative in PC space), while the relationship with salinity and sigma-t was negative. So, while these results may appear to contradict other findings in this paper, notably a long-term increase in SST using the 50+ year HadISST data set and a decadal increase in seabird abundance, they do not. Temperature in PC space has the same relationship to seabirds on interannual and decadal scales, and in both cases the relationships were positive.

On the decadal scale, we found that seabird abundances were increasing, particularly in late summer, and suggest that this is related to the timing of peak chlorophyll concentrations, with shifts of late spring and late summer peaks occurring earlier and later in each year, respectively. Thus, we postulate that the length of the growing season in the Alaska Gyre has extended over the period of study. This is supported by the April (advance) and October (delay) temporal shifts in temperature (for more details see Burrows et al. 2011). Notably, as there were no trends in chlorophyll concentrations, the increases in seabird abundance observed in this study may be explained by changes in the timing of peak chlorophyll 
Table 4. Negative binomial regression of seabird abundances against $P C 1_{\text {env }}$. Models included terms area and season (categorical). Dark shearwaters consist of both sooty and short-tailed species. ${ }^{*} \mathrm{p}<0.1,{ }^{* *} \mathrm{p}<0.05,{ }^{* * *} \mathrm{p}<0.01$

\begin{tabular}{|c|c|c|c|c|}
\hline \multirow[b]{2}{*}{ Species } & \multicolumn{2}{|c|}{$\longrightarrow$ Lag $0 \mathrm{mo}-$} & \multicolumn{2}{|c|}{$\longrightarrow$ Lag $4 \mathrm{mo}-$} \\
\hline & Coefficient & $Z$-score & Coefficient & $Z$-score \\
\hline All species & -0.142 & $-1.72^{*}$ & -0.165 & $-2.31^{* *}$ \\
\hline \multicolumn{5}{|l|}{ Alcids } \\
\hline Ancient murrelet & -0.773 & $-2.14^{* *}$ & 0.023 & 0.08 \\
\hline Cassin's auklet & -0.343 & $-1.96^{* *}$ & -0.262 & -1.44 \\
\hline Common murre & -0.182 & -0.95 & -0.217 & -1.37 \\
\hline Rhinoceros auklet & -0.354 & $-2.43^{* *}$ & -0.323 & $-2.78^{* * *}$ \\
\hline Tufted puffin & 0.033 & 0.27 & -0.106 & -0.85 \\
\hline \multicolumn{5}{|l|}{ Larids } \\
\hline Black-legged kittiwake & -0.033 & -0.17 & -0.313 & -1.54 \\
\hline Glaucous-winged gull & -0.452 & $-2.71^{* * *}$ & -0.233 & $-1.88^{*}$ \\
\hline \multicolumn{5}{|l|}{ Procellarids } \\
\hline Mottled petrel & -0.214 & -0.86 & 0.326 & 1.49 \\
\hline Northern fulmar & 0.066 & 0.38 & -0.089 & -0.45 \\
\hline Pink-footed shearwater & 0.502 & 0.78 & -0.419 & -0.80 \\
\hline Dark shearwaters & -0.266 & $-2.00^{* *}$ & -0.344 & $-1.90^{*}$ \\
\hline \multicolumn{5}{|l|}{ Albatrosses } \\
\hline Black-footed albatross & -0.038 & -0.45 & -0.186 & $-2.24^{* *}$ \\
\hline Laysan albatross & 0.002 & 0.99 & -0.155 & -0.80 \\
\hline \multicolumn{5}{|l|}{ Storm-petrels } \\
\hline Fork-tailed Storm-petrel & -0.093 & -1.16 & -0.180 & $-2.25^{* *}$ \\
\hline Leach's Storm-petrel & -0.154 & $-2.11^{* *}$ & -0.187 & $-2.39^{* *}$ \\
\hline
\end{tabular}

to be staying in the Alaska Gyre for a longer period of time each year, a pattern related to changes in the phenology of primary productivity and possibly 'bottomup' trophic interactions. Northwestward isotherm displacement suggests possible improvements in habitat quality (warming) for seabirds in this region.

Studies of seabirds at sea have a distinct advantage over studies of seabirds at colonies in that environmental conditions can be measured concurrently at appropriate temporal and spatial scales, thereby facilitating mechanistic understanding of physical-biological coupling. The importance of this study lies in its broad spatial scale and seasonal sampling along with the hydrographic data collected in tandem and applied to multiple seabird species. With shipboard surveys one can map and assess changes in the distribution and abundance of multiple species simultaneously and attribute these changes to environmental conditions. We expect that additional insight will be provided by these sea-going pro-

values alone. We are not suggesting that seabirds are responding directly to changes in phytoplankton, but rather that increased phytoplankton provide the basis for greater productivity and larger biomass of forage nekton, including fish and zooplankton. Our new working hypothesis is that the extended growing season enhances food availability in late summer, thus enticing seabirds to stay in the gyre longer during each year.

\section{Re-distribution of seabirds to the Alaska Gyre?}

Sydeman et al. (2009) compared overall seabird abundance and species richness from the CalCOFI (1987-2006) and Line P programs (1996-2006), and found a decline in abundance and diversity in the Southern California Bight and an increase in abundance and diversity in the southeastern Gulf of Alaska. To what extent could range expansions or contractions explain patterns of change in the Alaska Gyre seabird community? This study and others (Hyrenbach \& Veit 2003, Woehler et al. 2003, Ainley \& Hyrenbach 2010, Péron et al. 2010) have demonstrated changes in relative abundance of seabirds that could suggest large-scale re-distributions. In this case, locally-breeding and migrant seabirds appeared grams, especially with increasing lengths of the time series in future years. This study provides key reference points for developing spatially explicit and seasonally sensitive models of climate-seabird interactions in the Northeast Pacific.

Acknowledgements. We thank the Department of Fisheries and Oceans Canada (DFO) and Environment Canada (EC) for facilitating seabird studies on Line P. In particular, we appreciate the captain and crew of the 'John P. Tully' for accommodating our field observers. We appreciate the dedication and fortitude of $\mathrm{M}$. Bentley, our primary observer, as well as all other seabird observers for their long hours in the field. M. Robert (DFO) provided a description of the methods used to collect physical oceanographic data along Line P for this manuscript. N. Sarkar (Naval Postgraduate School) aided with the interpretation of $\mathrm{PC}_{\text {env }}$ and our understanding of stratification in the Gulf of Alaska. R. Suryan (Oregon State University) processed and provided the chl a data. Over the years, funding for various parts of this work was provided by the EC, the National Fish and Wildlife Foundation, the Packard Foundation via the Resources Legacy Fund Foundation, the National Science Foundation, and donors to the Farallon Institute.

\section{LITERATURE CITED}

Ainley DG, Hyrenbach KD (2010) Top-down and bottom-up factors affecting seabird population trends in the California Current system (1985-2006). Prog Oceanogr 84: 242-254 
Barbraud C, Weimerskirch H (2006) Antarctic birds breed later in response to climate change. Proc Natl Acad Sci USA 103:6248-6251

Batten SD, Mackas DL (2009) Shortened duration of the annual Neocalanus plumchrus biomass peak in the Northeast Pacific. Mar Ecol Prog Ser 393:189-198

Beaugrand G, Kirby RR (2010) Climate, plankton and cod. Glob Change Biol 16:1268-1280

Bertram DF, Mackas DL, McKinnell SM (2001) The seasonal cycle revisited: interannual variation and ecosystem consequences. Prog Oceanogr 49:283-307

Burrows MT, Schoeman DS, Buckley LB, Moore P and others (2011) The pace of shifting climate in marine and terrestrial ecosystems. Science 334:652-655

> Byrd GV, Sydeman WJ, Renner HM, Minobe S (2008) Responses of piscivorous seabirds at the Pribilof Islands to ocean climate. Deep-Sea Res II 55:1856-1867

Crawford W, Galbraith J, Bolingbroke N (2007) Line P ocean temperature and salinity, 1956-2005. Prog Oceanogr 75: 161-178

> Cushing DH (1990) Plankton production and year-class strength in fish populations: an update of the match/ mismatch hypothesis. Adv Mar Biol 26:249-293

> Doney SC, Ruckelshaus M, Duffy JE, Barry JP and others (2012) Climate change impacts on marine ecosystems. Annu Rev Mar Sci 4:11-37

> Dorman JG, Powell TM, Sydeman WJ, Bograd SJ (2011) Advection and starvation cause krill (Euphausia pacifica) decreases in 2005 Northern California coastal populations: implications from a model study. Geophys Res Lett 38, L04605, doi: 10.1029/2010GL046245

Edwards M, Richardson AJ (2004) Impact of climate change on marine pelagic phenology and trophic mismatch. Nature 430:881-884

Freeland HJ, Cummins PF (2005) Argo: a new tool for environmental monitoring and assessment of the world's oceans, an example from the NE Pacific. Prog Oceanogr 64:31-44

Freeland HJ, Denman K, Wong CS, Whitney F, Jacques R (1997) Evidence of change in the winter mixed layer in the Northeast Pacific Ocean. Deep-Sea Res I 44:2117-2129

Hilbe JM (2011) Negative binomial regression, 2nd edn. Cambridge University Press, Cambridge

Hipfner JM (2005) Population status of the common murre Uria aalge in British Columbia, Canada. Mar Ornithol 33: $67-70$

> Hoegh-Guldberg O, Bruno JF (2010) The impact of climate change on the world's marine ecosystems. Science 328: 1523-1528

> Hsieh CH, Kim HJ, Watson W, Di Lorenzo E, Sugihara G (2009) Climate-driven changes in abundance and distribution of larvae of oceanic fishes in the southern California region. Glob Change Biol 15:2137-2152

Hyrenbach DK, Veit RR (2003) Ocean warming and seabird communities of the southern California Current System (1987-98): response at multiple temporal scales. DeepSea Res II 50:2537-2565

> Ji R, Edwards M, Mackas DL, Runge JA, Thomas AC (2010) Marine plankton phenology and life history in a changing climate: current research and future directions. J Plankton Res 32:1355-1368

- Levitus S, Antonov J, Boyer T (2005) Warming of the world ocean, 1955-2003. Geophys Res Lett 32, L02604, doi: 10.1029/2004GL021592

Lipsen MS, Crawford DW, Gower J, Harrison PJ (2007) Spa- tial and temporal variability in coccolithophore abundance and production of PIC and POC in the NE subarctic Pacific during El Niño (1998), La Niña (1999) and 2000. Prog Oceanogr 75:304-325

> Mackas DL, Goldblatt R, Lewis AG (1998) Interdecadal variation in developmental timing of Neocalanus plumchrus populations at Ocean Station P in the subarctic North Pacific. Can J Fish Aquat Sci 55:1878-1893

Mackas DL, Batten S, Trudel M (2007) Effects on zooplankton of a warmer ocean: recent evidence from the Northeast Pacific. Prog Oceanogr 75:223-252

O'Hara PD, Morgan KH, Sydeman WJ (2006) Primary producer and seabird associations with AVHRR-derived sea surface temperatures and gradients in the southeastern Gulf of Alaska. Deep-Sea Res II 53:359-369

Peña MA, Varela DE (2007) Seasonal and interannual variability in phytoplankton and nutrient dynamics along Line $P$ in the NE subarctic Pacific. Prog Oceanogr 75:200-222

Péron C, Authier M, Barbraud C, Delord K, Besson D, Weimerskirch $H$ (2010) Interdecadal changes in at-sea distribution and abundance of subantarctic seabirds along a latitudinal gradient in the Southern Indian Ocean. Glob Change Biol 16:1895-1909

Piatt JF, Harding AMA, Shultz M, Speckman SG, van Pelt TI, Drew GS, Kettle AB (2007) Seabirds as indicators of marine food supplies: Cairns revisited. Mar Ecol Prog Ser 352:221-234

Rodway MS, Lemon MJF (2011) Use of permanent plots to monitor trends in burrow-nesting seabird populations in British Columbia. Mar Ornithol 39:243-253

> Sarkar N, Royer TC, Grosch CE (2005) Hydrographic and mixed layer depth variability on the shelf in the northern Gulf of Alaska, 1974-1998. Cont Shelf Res 25:2147-2162

Schlatter RP (1984) The status and conservation of seabirds in Chile. In: Croxall JP, Evans PGH, Schreiber RWE (eds) Status and conservation of the world's seabirds. International Council for Bird Preservation, Cambridge, p 261-292

Scott D, Scofield P, Hunter C, Fletcher D (2008) Decline of sooty shearwaters, Puffinus griseus, on the Snares, New Zealand. Pap Proc R Soc Tasman 142:185-196

Sydeman WJ, Mills KL, Santora JA, Thompson SA and others (2009) Seabirds and climate in the California Current-a synthesis of change. CCOFI Rep 50:82-104

Sydeman WJ, Thompson SA, Santora JA, Henry MF, Morgan KH, Batten SD (2010) Macro-ecology of planktonseabird associations in the North Pacific Ocean. J Plankton Res 32:1697-1713

Tasker ML, Jones PH, Dixon T, Blake B (1984) Counting seabirds at sea from ships: a review of methods employed and a suggestion for a standardized approach. Auk 101:567-577

Whitney FA, Freeland HJ (1999) Variability in upper-ocean water properties in the NE Pacifc Ocean. Deep-Sea Res II 46:2351-2370

> Woehler EJ, Raymond B, Watts DJ (2003) Decadal-scale seabird assemblages in Prydz Bay, East Antarctica. Mar Ecol Prog Ser 251:299-310

Wong CS, Xie LS, Hsieh WW (2007) Variations in nutrients, carbon and other hydrographic parameters related to the $1976 / 77$ and 1988/89 regime shifts in the sub-arctic Northeast Pacific. Prog Oceanogr 75:326-342

Yen PPW, Sydeman WJ, Morgan KH, Whitney FA (2005) Top predator distribution and abundance across the eastern Gulf of Alaska: temporal variability and ocean habitat associations. Deep-Sea Res II 52:799-822 


\section{Appendix 1}

Table A1. Median survey date, number of survey days, and total area surveyed of each at-sea survey along Line P. No surveys took place in winter 1996, late spring 2005, or late summer 1997, 1998 and 2006

\begin{tabular}{|c|c|c|c|c|c|c|c|c|c|}
\hline \multirow[b]{2}{*}{ Year } & \multicolumn{3}{|c|}{ Median survey date } & \multicolumn{3}{|c|}{ No. of survey days } & \multicolumn{3}{|c|}{ Total area surveyed $\left(\mathrm{km}^{2}\right)$} \\
\hline & Winter & Late spring & Late summer & Winter & Late spring & Late summer & Winter & Late spring & Late summer \\
\hline 1996 & & 21 May & 23 Aug & & 14 & 13 & & 468 & 560 \\
\hline 1997 & 21 Feb & 18 Jun & & 10 & 16 & & 200 & 555 & \\
\hline 1998 & 24 Feb & 15 Jun & & 10 & 18 & & 467 & 716 & \\
\hline 1999 & 20 Feb & 13 Jun & $4 \mathrm{Sep}$ & 12 & 17 & 17 & 437 & 652 & 540 \\
\hline 2000 & 13 Feb & 6 Jun & 13 Sep & 10 & 11 & 12 & 393 & 802 & 451 \\
\hline 2001 & $14 \mathrm{Feb}$ & 12 Jun & 27 Aug & 13 & 25 & 10 & 401 & 902 & 405 \\
\hline 2002 & 15 Feb & 9 Jun & $5 \mathrm{Sep}$ & 14 & 19 & 16 & 760 & 637 & 723 \\
\hline 2003 & $12 \mathrm{Feb}$ & 6 Jun & $7 \mathrm{Sep}$ & 13 & 18 & 13 & 742 & 506 & 296 \\
\hline 2004 & 23 Feb & 9 Jun & 27 Aug & 8 & 15 & 14 & 208 & 253 & 376 \\
\hline 2005 & 18 Feb & & 25 Aug & 15 & & 15 & 385 & & 482 \\
\hline 2006 & 9 Feb & 18 Jun & & 16 & 6 & & 428 & 204 & \\
\hline
\end{tabular}

Table A2. Abundances for 15 seabird species that were analyzed. Species with $>200$ observations were included in the study

\begin{tabular}{|c|c|c|c|c|c|}
\hline Species & Scientific name & $\begin{array}{l}\text { No. of } \\
\text { birds }\end{array}$ & Species & Scientific name & $\begin{array}{l}\text { No. of } \\
\text { birds }\end{array}$ \\
\hline Alcids & & & Shearwaters and petrels & & \\
\hline Ancient murrelet & Synthliboramphus antiquus & 356 & Mottled petrel & Pterodroma inexpectata & 393 \\
\hline Cassin's auklet & Ptychoramphus aleuticus & 1667 & Northern fulmar & Fulmarus glacialis & 2784 \\
\hline Common murre & Uria aalge & 2730 & Pink-footed shearwater & Puffinus creatopus & 760 \\
\hline Rhinoceros auklet & Cerorhinca monocerata & 1431 & Dark shearwaters & Puffinus griseus and & 13789 \\
\hline Tufted puffin & Fratercula cirrhata & 611 & (sooty and short-tailed) & P. tenuirostris & \\
\hline \multicolumn{3}{|l|}{ Gulls } & \multicolumn{3}{|c|}{ Albatrosses and storm-petrels } \\
\hline Black-legged kittiwake & Rissa tridactyla & 1375 & Black-footed albatross & Phoebastria nigripes & 1158 \\
\hline \multirow[t]{3}{*}{ Glaucous-winged gull } & Larus glaucescens & 1386 & Laysan albatross & Phoebastria immutabilis & 382 \\
\hline & & & Fork-tailed storm-petrel & Oceanodroma furcata & 2278 \\
\hline & & & Leach's storm-petrel & Oceanodroma leucorhoa & 9225 \\
\hline
\end{tabular}

